\title{
Utilization of Leucaena leucocephala in Traditional Fattening Program of Bali Cattle in Amarasi
}

\author{
M. L. Lani ${ }^{\mathrm{a}}$, L. Abdullah ${ }^{\mathrm{b}, *}$, \& R. Priyanto ${ }^{\mathrm{c}}$ \\ ${ }^{a}$ Graduate School of Animal Nutrition and Feed Science, Bogor Agricultural University \\ bepartment of Nutrition and Feed Technology, Faculty of Animal Science, Bogor Agricultural University \\ bDepartment of Animal Production and Technology, Faculty of Animal Science, Bogor Agricultural University \\ Jalan Agatis, Kampus IPB Darmaga, Bogor 16680, Indonesia \\ (Received 21-08-2014; Reviewed 26-09-2014; Accepted 25-02-2015)
}

\begin{abstract}
This field study was aimed to evaluate the availability and the utility of forage on Bali cattle in Amarasi system in dry land area such as Kupang. Amarasi system is a fattening production system (paronisasi), which traditionally utilizes Leucaena leucocephala forage in dry season of Amarasi region. This field study was conducted during the period of July to December 2013 in Oesena and Merbaun Villages. The method used in this research was field survey. This type of survey was used to identify the forage availability and utility for Bali cattle; including determining the level of feed intake, measuring carrying capacity of both observe villages, and recording body weight of cattle. Cluster random sampling was applied in this study to determine sample used in the research, those were two villages with different altitudes, namely Oesena Village and Merbaun Village. Data were analyzed descriptively to describe the related existing conditions in the field. T-test was conducted to determine leucaena consumption and Bali cattle body weight in both villages. The results showed that during observation period, availability of leucaena forage for cattle was low based on dry matter intake 3.60 and $3.58 \mathrm{~kg} / \mathrm{head} / \mathrm{day}$, which led to low consumption of cattle. Nevertheless, the use of leucaena in this system increased average body weight gain of Bali cattle up to $0.77 \mathrm{~kg} / \mathrm{day}$, due to high crude protein consumption. The conclusion of this study was the availability of leucaena as Bali cattle feed did not meet the cattle needs, but the use of leucaena increased the average of Bali cattle body weight gain.
\end{abstract}

Key words: amarasi system, Bali cattle, Leucaena leucocephala, paronisasi

\section{ABSTRAK}

Penelitian ini bertujuan untuk mengevaluasi ketersediaan dan penggunaan hijauan pakan sapi Bali pada sistem Amarasi di lahan kering. Sistem amarasi adalah sebuah sistem penggemukan (paronisasi) ternak sapi Bali yang khas berbasis pakan hijauan lamtoro (Leucaena leucocephala) pada musim kemarau di wilayah Amarasi. Penelitian ini dilaksanakan pada bulan Juli sampai dengan Desember 2013 di Desa Oesena dan Desa Merbaun Kabupaten Kupang Propinsi Nusa Tenggara Timur. Metode yang digunakan adalah survei lapang untuk mengidentifikasi hijauan pakan ternak yang terdapat di kandang, mengukur tingkat konsumsi pakan ternak, besarnya kapasitas tampung pada kedua desa dan pertambahan bobot badan ternak sapi Bali. Pengambilan sampel dilakukan menggunakan cluster random sampling. Dua desa dengan ketinggian berbeda dipilih, yaitu Desa Oesena dan Desa Merbaun. Data dianalisis secara deskriptif untuk menggambarkan kondisi di lapangan. Uji $t$ dilakukan untuk mengetahui nilai bobot badan konsumsi lamtoro pada kedua desa. Hasil penelitian menunjukkan bahwa nilai konsumsi lamtoro, yaitu 3.60 dan $3.58 \mathrm{~kg} / \mathrm{ekor} / \mathrm{hari}$ serta kapasitas tampung di dua desa yang rendah, namun pertambahan bobot badan sapi Bali meningkat hingga $0.77 \mathrm{~kg} / \mathrm{ekor}$ hari yang disebabkan oleh tingginya konsumsi protein kasar. Kesimpulan dari penelitian ini adalah ketersediaan lamtoro sebagai pakan sapi Bali belum memenuhi kebutuhan ternak, namun penggunaannya meningkatkan bobot badan sapi Bali.

Kata kunci: Leucaena leucocephala, paronisasi, sistem amarasi, sapi bali

*Corresponding author:

E-mail: $\underline{\text { lukiabdullah@gmail.com }}$ 


\section{INTRODUCTION}

The forage portion in ruminant ration reaches approximately $3 \%$ of the body weight. Nutritionally leucaena, is source of fiber, mineral and protein, which traditionally fulfill animal requirements for growth. The difficulties in providing sustainable amount of forage often occur in Kupang due to long dry season. It causes low productivity of ruminants.

Amarasi region is located in Kupang Regency in East Nusa Tenggara province and consists of four sub districts namely Amarasi, West Amarasi, East Amarasi, and South Amarasi. The climates in these areas are influenced by the monsoon winds from Australia. Monthly rainfall ranges between $4 \mathrm{~mm}$ (in October) to $316 \mathrm{~mm}$ (in February) with humidity ranging from $64 \%$ to $84 \%$ (BPS, 2013). In Amarasi, farmers applied a traditional fattening system called "paronisasi" by using only leucaena as one of the most important forage on dry season.

Leucaena is daily feed on dry season in this system by cut and curry method. Farmers grow leucaena in their garden and harvest the forage regularly. This system was initially applied in 1930 under the rule of the Dutch government in Baun Village of Amarasi region (Metzner, 1981) which then being reinforced by the local customs authorities in 1932. Regulations made by the local authority (king) have significantly supported this system to a success story compared to breeder-farmers in other regions of the province.

Since this system was introduced, great numbers of farmers are interested in implementing this system and are entirely relying on L. leucocephala as the main feed source. Forage L. leucocephala can be used as a protein, minerals, and vitamin sources (Haque et al., 2008; Kang et al., 2012). Dahlanuddin et al. (2013) reported that Bali cattle fed leucaena increase average daily gain by 0.47 $\mathrm{kg} / \mathrm{head} / \mathrm{d}$. Furthermore, addition of S. cerevisiae and $L$. leucocephala on low-quality feed improved nutrient digestibility and cattle performance (Herawaty et al., 2013). In previous studies, supplementation of L. leucocephala increased total dry matter intake and crude protein digestibility in goats (Aregheore \& Parera, 2004; Kanani et al., 2005; Abdulrazak et al., 2006; Yousuf et al., 2007; Fasae et al., 2011), as feed additive for growing lambs and cow's milk production (Salem et al., 2011; Salem et al., 2014).

Nevertheless, the flea's attack in the early 1986 had tremendously destroyed leucaena stands and directly influenced the declining of livestock productivity in Amarasi. Leucaena shortage in beef cattle affected the fattening program period is longer and the number of cattle are fattened be less. In such condition, the Amarasi system became better and are flea's tolerant leucaena being re-cultivated. Based on the above information this study was undertaken to evaluate the availability and the use of leucaena (L. leucocephala) on Amarasi system in Kupang.

\section{MATERIALS AND METHODS}

\section{Leucaena Intake Measurement}

Edible part of leucaena intake was recorded by weighing the forage before feeding and the residue of leucaena on the next day. Forage intake was observed for seven consecutive days. The number of respondents were 15 farmers for each villages and coded as F1, F2, until F15 to collect primary data including leucaena consumption, chest circumference to estimate body weight, and nutrient quality of leucaena. These farmers were part of total respondent (75) that were interviewed.

\section{Research Accomplishment}

The survey was conducted to investigate information regarding cattle condition by farmers, field, and farmer's profiles. Along with this, questionnaires were used to obtain information on general condition of production system and feed resources in farm level. Data used in the study were primary and secondary data. Primary data were obtained from the results of leucaena intake, chemical composition of forage and cattle body weight. Secondary data contained climatic data, village resources agriculture.

Cluster random sampling was applied in this study to determine sample used in the research, those were two villages with different altitudes, namely Oesena Village located in the hills at $500 \mathrm{~m}$ above sea surface in Amarasi sub district and Merbaun Village which located near the shore areas at $30 \mathrm{~m}$ above sea surface in West Amarasi sub district (BPS, 2013).

The number of samples was calculated using the following formula (Som, 1996):

$\mathrm{n}=\mathrm{N} /\left(1+\mathrm{Ne}^{2}\right)$

Notes:

$\mathrm{N}$ : total farmers

e : error $(10 \%)$

n : total sample

The number of respondents was 75 farmer families from both villages. The information regarding farmer, number of cattle, and forage supply patterns were obtained by using questionnaires. T-test was used to determine Bali cattle body weight and leucaena consumption value in both villages.

\section{Carrying Capacity Measurement}

Carrying capacity is a number of cattle that can graze on a pasture without destroying the land, crops, and livestock. The carrying capacity was calculated based on the space of plant with assuming the population of leucaena was 2500 trees/ha and plant spacing was $2 \times 2 \mathrm{~m}$ and cutting frequency was 3 times in dry season (8 months). Carrying capacity was calculated using a modified method of Halls et al. (1964). 


\section{Body Weight Gain Estimation}

Body weight gains were estimated from chest circumference using the pattern Zurahmah (2011).

$$
\mathrm{BW}=2.62 \mathrm{CC}-192
$$

Notes:

$\mathrm{BW}=$ body weight $(\mathrm{kg})$

$\mathrm{CC}=$ chest circumference $(\mathrm{cm})$

Bali cattle body weight daily gain was calculated using the following formula:

$\mathrm{ADG}=[$ body weight week $\mathrm{n}$ - body weight $\mathrm{n}(\mathrm{n}-1)] / 7$

\section{Data Analysis}

The data were analyzed descriptively to describe the general state of the research sites. Those were temperatures, humidity, rainfall and livestock rearing systems and patterns of green fodder supply that can support the efforts of ruminant livestock in East Nusa Tenggara.

\section{Analysis of Chemical Composition of Leucaena}

The chemical composition of leucaena forage was analyzed using proximate analysis method (AOAC, 2005) and Van soest (Tillman, 1998). Forage feed samples were taken from the both Oesena and Merbaun vilages.

Total digestible nutrient (TDN) from leucaena forage was calculated using the following formula as described by Hartadi et al. (1980):

TDN $(\%)=-54.572+6.769(\mathrm{CF})-51.083(\mathrm{EE})+1.851$

$(\mathrm{NFE})-0.334(\mathrm{CP})-0.049(\mathrm{CF})^{2}+3.384(\mathrm{EE})^{2}$

$-0.086(\mathrm{CF})(\mathrm{NFE})+0.687(\mathrm{EE})(\mathrm{NFE})+0.942$

(EE) $(\mathrm{CP})-0.112(\mathrm{EE})^{2}(\mathrm{CP})$

Notes:

CF : crude fiber

EE : ether extract

NFE : nitrogen-free extract

$\mathrm{CP}$ : crude protein

\section{RESULTS AND DISCUSSION}

\section{General Condition of the Research Area}

Farmer in Oesena Village and the Merbaun Village spread evenly because of the existence land in the villages. The lands were used not only for L. leucocephala but also to graze livestock traditionally in both extensive and semi-intensive system. In addition the cattle were kept in cage during the day and some of the Bali cattle kept freely around the house. L. leucocephala was planted as fence around the house in some farmers, but some other farmers planted leucaena as garden to fed Bali cattle.

The average of farmer ages in both villages were 33-48 years old. Farming has become an integral part of the culture and is existed as a complementary income generator that is inherited from each generation. The farmers came from different formal education background such as elementary, junior high school, senior high school and bachelor degree (S1), and also farmers who had not a formal education. The main occupations of the farmers in both villages were varied, they were mostly working as a farmer, gardener, and motorcycle taxi drivers. Hence, it could be assumed the average income of farmers without fattening program in economic standard of farmers were low. As it was considered as another source of income, the farmers took care of their cattle once the main occupation had finished. The profit from derived fattening was budgeted for paying children school fee, marriage, and other traditional events. On average, each farmer in the two villages had their own 2-6 cattle as the heritance from the parents as well as purchasing their own cattle.

Bali cattle production system used in the two villages was semi-intensive, cattle are tied up and then being fed with leucaena twice a day in the morning and afternoon. This system is also called "paronisasi". Defoliation systems of leucaena forage conducted in the village is cut and carry. Residue of leucaena forage in the form of twigs and stems are collected by the farmers and are used as firewood and poles for construction. Another function of L. leucocephala was reforestation, poles for construction, firewood, shade in permanent plantations, traditional medicine (Nehdy et al., 2014), pulp production (Lopez et al., 2008), green manuring (Sharma \& Behera, 2010), and in wood production (Prasad et al., 2011). Forages given to cattle were collected from their own garden or around the yard. There is a law that is regulated by the government since ancient time that is when farmers stole forage from other breeders, they will have to pay approximately 1 million IDR. The law enforces the farmers to grow leucaena in their garden. In accordance to the results of our interview, each farmer in average possessed 2.5 ha of leucaena field in Oesena, while in Merbaun Village they had 6.25 ha.

Based on the field observation, Psyllid was found in some stands of leucaena in both villages. Integrated pest management applied by the community and village government to eliminate the fleas was entirely successful. Since leucaena was still considered as a major feed in Amarasi, new tolerant fleas varieties of Lamtoro cv. Tarrambah, was extensively cultivated in the area (Nulik et al., 2013).

Leucaena has been chosen due to its ability to adapt to a longer dry season and palatable. Besides, support from the government to apply the forestation program,

Table 1. Chemical composition (\%) of leucaena (dry matter basis)

\begin{tabular}{lcc}
\hline \multicolumn{1}{c}{ Nutrients } & Oesena village & Merbaun village \\
\hline Crude protein & 27.35 & 19.88 \\
Crude fiber & 18.26 & 14.88 \\
Crude fat & 3.21 & 5.61 \\
Nitrogen-free extract & 43.03 & 50.70 \\
Neutral detergent fiber & 71.19 & 70.55 \\
Acid detergent fiber & 44.99 & 64.83 \\
\hline
\end{tabular}

Note: Analyzed by Feed Technology Laboratory, Faculty of Animal Science, Bogor Agricultural University 
pave the way to make leucaena as the major feed crop in Amarasi until now.

\section{Nutrient Quality of Leucaena}

The chemical compositions of leucaena forage in both study areas were not significantly different. Crude protein contain in leucaena forage grown in Oesena (mountainous) 27.35\% was higher than Merbaun which was located nearby the beach $19.88 \%$ (Table 1 ).

Protein content in Oesena village was higher than Merbaun village, this could be due to the fertility of the soil and climate. Merbaun village is located near the beach so it has a higher salinity levels and lower rainfall than Oesena village which stated in the hills.

\section{Leucaena Consumption}

The average of dry matter intake of leucaena (DMIL) in Oesena was $3.60 \pm 0.83 \mathrm{~kg} / \mathrm{head} / \mathrm{d}$, while in Merbaun Village DMIL was average of $3.59 \pm 0.72 \mathrm{~kg} / \mathrm{head} / \mathrm{d}$ (Table 2). The DM consumption on rates of leucaena in both village were still low about $1.59 \%$ of body life weight and $2.05 \%$ of body life weight or approximately $53 \%$ and $72 \%$ of total leucaena feed in Oesena and Merbaun, respectively. According to Kearl (1982), daily DMI for cattle as about $2.8 \%$ body weight. Based on the calculation of the consumption, the weight of the cattle in the two villages were livestock feed shortage. Kearl (1982) states that the average cow body weight between 150$200 \mathrm{~kg}$ with an increase in body weight $0.50 \mathrm{~kg} / \mathrm{head} / \mathrm{d}$ of dry matter intake $4.2 \mathrm{~kg} / \mathrm{h} /$ day or $2.8 \%$. The shortages occurred due to long period of drought that lead to the declining of feed availability. Prolonged drought and high temperatures resulted in lost of leucaena leaves. Then, the flea invasions also caused the two villages to the lack of forage availability. Nevertheless cattle in these two villages were able to utilize nutrients leucaena well; this was followed by an increase in body weight of Bali cattle in wet season. DMIL in Merbaun is significantly higher $\mathrm{P}<0.05$ (T-test) than those in Oesena. This was perhaps due to greater area of leucaena possessed by farmers in Merbaun than in Oesena.

\section{Crude Protein and TDN Consumptions}

Consumption of crude protein in Oesena Village was higher $0.98 \pm 0.21 \mathrm{~kg} / \mathrm{head} / \mathrm{d}$ than Merbaun Village $0.71 \pm 0.08 \mathrm{~kg} / \mathrm{head} / \mathrm{d}$ (Table 2 ), it was because of the high crude protein content in leucaena forage from Oesena $(27.35 \%)$. Crude protein consumption in the cattle was higher than crude protein of requirement $0.57-0.67 \mathrm{~kg} / \mathrm{d}$ as recommended by Kearl (1982).

TDN consumption of two villages did not much different, and it fulfilled the TDN need in cattle. TDN consumption in Oesena and Merbaun village was $2.61 \pm 0.33 \mathrm{~kg} / \mathrm{head} / \mathrm{d}$ and $3.87 \pm 0.46 \mathrm{~kg} / \mathrm{head} / \mathrm{d}$ (Table 2). Based on the calculations of TDN requirement Kearl (1982) standard for $150-200 \mathrm{~kg}$ cattle body weight was $2.75-3.55 \mathrm{~kg} / \mathrm{d}$.

\section{Bali Cattle Body Weight Gain}

Average daily gain (ADG) of cattle in two villages were varied. It can be grouped into two ADG level ie: $\mathrm{ADG} \leq 0.50 \mathrm{~kg} / \mathrm{head} / \mathrm{d}$ as group $\mathrm{A}$ and ADG $\geq 0.50 \mathrm{~kg} /$ head/d as group B. The lowest daily gain average of Bali cattle of group A in the Oesena was $0.17 \mathrm{~kg} / \mathrm{head} / \mathrm{d}$ and Merbaun Village was $0.32 \mathrm{~kg} / \mathrm{head} / \mathrm{d}$ (Table 3). Cattle in group A was growing cattle, so feed consumed was used for the growth of the animal itself. The highest ADG of Bali cattle of group B in the Oesena Village was

Table 2. Daily dry matter intake, crude protein, and total digestible nutrient of Bali Cattle consumed leucaena in Oesena and Merbaun Villages

\begin{tabular}{|c|c|c|c|c|c|c|c|c|c|c|}
\hline \multirow{2}{*}{ No } & \multicolumn{2}{|c|}{ Body Weight (kg) } & \multicolumn{2}{|c|}{ DM Intake (kg/head/d) } & \multicolumn{2}{|c|}{ DM Intake (\% BW) } & \multicolumn{2}{|c|}{$\begin{array}{c}\text { CP Consumption } \\
(\mathrm{kg} / \mathrm{head} / \mathrm{d})\end{array}$} & \multicolumn{2}{|c|}{$\begin{array}{c}\text { TDN Consumption } \\
(\mathrm{kg} / \mathrm{head} / \mathrm{d})\end{array}$} \\
\hline & $\begin{array}{l}\text { Oesena } \\
\text { Village }\end{array}$ & $\begin{array}{c}\text { Merbaun } \\
\text { Village }\end{array}$ & $\begin{array}{l}\text { Oesena } \\
\text { Village }\end{array}$ & $\begin{array}{c}\text { Merbaun } \\
\text { Village }\end{array}$ & $\begin{array}{l}\text { Oesena } \\
\text { Village }\end{array}$ & $\begin{array}{c}\text { Merbaun } \\
\text { Village }\end{array}$ & $\begin{array}{l}\text { Oesena } \\
\text { Village }\end{array}$ & $\begin{array}{c}\text { Merbaun } \\
\text { Village }\end{array}$ & $\begin{array}{l}\text { Oesena } \\
\text { Village }\end{array}$ & $\begin{array}{c}\text { Merbaun } \\
\text { Village }\end{array}$ \\
\hline F1 & 208.89 & 207.50 & $4.07 \pm 0.41$ & $3.75 \pm 0.29$ & $1.95 \pm 0.19$ & $1.81 \pm 0.14$ & $1.12 \pm 0.11$ & $0.75 \pm 0.05$ & $2.95 \pm 0.29$ & $4.04 \pm 0.31$ \\
\hline $\mathrm{F} 2$ & 203.62 & 202.32 & $4.82 \pm 1.16$ & $3.53 \pm 0.15$ & $2.37 \pm 0.57$ & $1.75 \pm 0.08$ & $1.32 \pm 0.32$ & $0.70 \pm 0.03$ & $3.49 \pm 0.84$ & $3.80 \pm 0.16$ \\
\hline F3 & 220.00 & 224.41 & $4.67 \pm 0.84$ & $3.58 \pm 0.30$ & $2.12 \pm 0.38$ & $1.59 \pm 0.14$ & $1.28 \pm 0.23$ & $0.71 \pm 0.06$ & $3.38 \pm 0.61$ & $3.85 \pm 0.33$ \\
\hline $\mathrm{F} 4$ & 268.73 & 140.41 & $4.50 \pm 0.40$ & $3.73 \pm 1.37$ & $1.67 \pm 0.15$ & $2.66 \pm 0.97$ & $1.23 \pm 0.11$ & $0.74 \pm 0.25$ & $3.26 \pm 0.29$ & $4.02 \pm 1.47$ \\
\hline F5 & 211.15 & 141.72 & $2.84 \pm 0.37$ & $2.73 \pm 0.76$ & $1.34 \pm 0.18$ & $1.93 \pm 0.53$ & $0.78 \pm 0.10$ & $0.54 \pm 0.14$ & $2.06 \pm 0.27$ & $2.94 \pm 0.82$ \\
\hline F6 & 214.10 & 145.33 & $4.68 \pm 1.71$ & $4.89 \pm 1.02$ & $2.18 \pm 0.80$ & $3.36 \pm 0.70$ & $1.28 \pm 0.47$ & $0.97 \pm 0.19$ & $3.39 \pm 1.24$ & $5.26 \pm 1.10$ \\
\hline F7 & 237.52 & 192.98 & $3.12 \pm 0.99$ & $3.61 \pm 0.14$ & $1.32 \pm 0.42$ & $1.87 \pm 0.08$ & $0.85 \pm 0.27$ & $0.72 \pm 0.03$ & $2.27 \pm 0.72$ & $3.88 \pm 0.16$ \\
\hline F8 & 260.72 & 153.51 & $3.59 \pm 0.59$ & $3.90 \pm 1.19$ & $1.38 \pm 0.23$ & $2.54 \pm 0.77$ & $0.98 \pm 0.16$ & $0.77 \pm 0.22$ & $2.61 \pm 0.43$ & $4.20 \pm 1.28$ \\
\hline F9 & 234.08 & 163.01 & $3.76 \pm 1.67$ & $3.81 \pm 0.41$ & $1.61 \pm 0.71$ & $2.34 \pm 0.25$ & $1.03 \pm 0.46$ & $0.76 \pm 0.08$ & $2.73 \pm 1.21$ & $4.10 \pm 0.45$ \\
\hline F10 & 201.00 & 172.18 & $2.68 \pm 0.40$ & $4.42 \pm 1.10$ & $1.34 \pm 0.20$ & $2.57 \pm 0.63$ & $0.73 \pm 0.11$ & $0.88 \pm 0.20$ & $1.95 \pm 0.29$ & $4.76 \pm 1.17$ \\
\hline F11 & 183.97 & 98.17 & $3.58 \pm 0.66$ & $4.09 \pm 1.22$ & $1.95 \pm 0.36$ & $4.16 \pm 1.23$ & $0.98 \pm 0.18$ & $0.81 \pm 0.22$ & $2.60 \pm 0.48$ & $4.40 \pm 1.30$ \\
\hline F12 & 213.51 & 230.80 & $2.48 \pm 0.60$ & $1.77 \pm 0.59$ & $1.16 \pm 0.28$ & $0.77 \pm 0.26$ & $0.68 \pm 0.16$ & $0.35 \pm 0.11$ & $1.80 \pm 0.43$ & $1.91 \pm 0.64$ \\
\hline F13 & 288.44 & 216.07 & $3.91 \pm 0.61$ & $3.83 \pm 0.21$ & $1.36 \pm 0.21$ & $1.77 \pm 0.10$ & $1.07 \pm 0.17$ & $0.76 \pm 0.04$ & $2.84 \pm 0.44$ & $4.12 \pm 0.23$ \\
\hline F14 & 222.68 & 206.24 & $2.49 \pm 0.33$ & $3.12 \pm 0.58$ & $1.12 \pm 0.15$ & $1.51 \pm 0.28$ & $0.68 \pm 0.09$ & $0.62 \pm 0.11$ & $1.80 \pm 0.24$ & $3.36 \pm 0.63$ \\
\hline F15 & 236.34 & 182.33 & $2.78 \pm 0.46$ & $3.13 \pm 0.44$ & $1.18 \pm 0.20$ & $1.72 \pm 0.24$ & $0.76 \pm 0.13$ & $0.62 \pm 0.08$ & $2.02 \pm 0.34$ & $3.37 \pm 0.47$ \\
\hline Average & $226.99 \pm 28.00^{\mathrm{a}}$ & $178.46 \pm 37.72^{\mathrm{b}}$ & $3.60 \pm 0.45$ & $3.58 \pm 0.43$ & $1.60 \pm 0.21^{\mathrm{b}}$ & $2.10 \pm 0.53^{\mathrm{a}}$ & $0.98 \pm 0.21$ & $0.71 \pm 0.08$ & $2.61 \pm 0.33$ & $3.87 \pm 0.46$ \\
\hline
\end{tabular}

Note: Means in the same row with different superscripts differ significantly $(\mathrm{P}<0.05) . \mathrm{F}=\mathrm{Farmers}, \mathrm{BW}=\mathrm{Body}$ Weight, $\mathrm{DM}=\mathrm{Dry} \mathrm{Matter}, \mathrm{CP}=\mathrm{Crude}$ Protein, TDN= Total Digestible Nutrient. 
Table 3. The average daily gain (ADG) of Bali cattle observed in Oesena and Merbaun Village

\begin{tabular}{|c|c|c|c|c|c|c|c|}
\hline \multicolumn{4}{|c|}{ Group A (ADG $\leq 0.50$ kg/head/d) } & \multicolumn{4}{|c|}{ Group B (ADG $\geq 0.50$ kg/head/d) } \\
\hline \multicolumn{2}{|c|}{ Oesena Village } & \multicolumn{2}{|c|}{ Merbaun Village } & \multicolumn{2}{|c|}{ Oesena Village } & \multicolumn{2}{|c|}{ Merbaun Village } \\
\hline Farmers & ADG & Farmers & ADG & Farmers & ADG & Farmers & ADG \\
\hline $\mathrm{F} 1$ & 0.32 & F1 & 0.32 & F8 & 0.64 & F6 & 1.12 \\
\hline F2 & 0.27 & F2 & 0.39 & F9 & 0.80 & F7 & 0.64 \\
\hline F3 & 0.21 & F3 & 0.05 & F10 & 0.80 & F8 & 0.86 \\
\hline $\mathrm{F} 4$ & 0.27 & $\mathrm{~F} 4$ & 0.37 & F11 & 0.81 & F9 & 0.80 \\
\hline F5 & 0.00 & F5 & 0.48 & F12 & 0.75 & F10 & 0.67 \\
\hline F6 & 0.11 & & & F13 & 0.70 & F11 & 0.70 \\
\hline \multirow[t]{4}{*}{ F7 } & 0.00 & & & F14 & 0.86 & F12 & 1.07 \\
\hline & & & & F15 & 0.75 & F13 & 0.56 \\
\hline & & & & & & F14 & 0.52 \\
\hline & & & & & & F15 & 0.72 \\
\hline Average & 0.17 & & 0.32 & & 0.76 & & 0.77 \\
\hline
\end{tabular}

$0.76 \mathrm{~kg} / \mathrm{head} / \mathrm{d}$ and Merbaun Village was $0.77 \mathrm{~kg} / \mathrm{head} / \mathrm{d}$ (Table 3). The increased of Bali cattle ADG was caused by high protein consumption which was $0.98 \mathrm{~kg} / \mathrm{head} / \mathrm{d}$ in the Oesena Village and $0.71 \mathrm{~kg} / \mathrm{head} / \mathrm{d}$ in the Merbaun Village (Table 3). Kearl (1982) stated that the standard of protein consumption for cattle with ADG $0.50 \mathrm{~kg} / \mathrm{head} / \mathrm{d}$ was $0.60-0.70 \mathrm{~kg} / \mathrm{head} / \mathrm{d}$. The excess of the protein was converted into energy.

\section{Carrying Capacity}

The average of leucaena leaf dry matter production in both villages Oesena and Merbaun were 3.2 ton/ha and 2.4 ton/ha, respectively (Table 4 ). Leucaena production and carrying capacity were calculated based on population leucaena per hectares with a spacing $2 \times 2$ $\mathrm{m}$. Therefore, in one hectare of leucaena farm were 2500 trees by three times cutting during the dry season.

Season has an important role on the productivity of the leucaena farm, so that the rest leucaena period used was 70 days. In the dry season, the result of carrying ca-

Table 4. Forage production and carrying capacity in Oesena and Merbaun Village

\begin{tabular}{lcc}
\hline Component & $\begin{array}{c}\text { Oesena } \\
\text { village }\end{array}$ & $\begin{array}{c}\text { Merbaun } \\
\text { village }\end{array}$ \\
\hline $\begin{array}{l}\text { Leucaena production (kg dry } \\
\text { matter/plant) }\end{array}$ & 0.49 & 0.36 \\
$\begin{array}{l}\text { Leucaena production in dry } \\
\text { season (ton/ha) }\end{array}$ & 3.20 & 2.40 \\
$\begin{array}{l}\text { Leucaena intake (\%) } \\
\begin{array}{l}\text { Bali cattle body weight average } \\
\text { (kg) }\end{array}\end{array}$ & $226.99 \pm 28.00$ & $178.46 \pm 37.72$ \\
$\begin{array}{l}\text { Leucaena consumption (kg/ } \\
\text { head/d) }\end{array}$ & 3.88 & 3.85 \\
$\begin{array}{l}\text { Carrying capacity in dry season } \\
(\text { AU/ha) }\end{array}$ & 1.94 & 1.43 \\
\hline
\end{tabular}

Note: $\mathrm{AU}=$ Animal unit. pacity at Oesena and Merbaun village was $1.94 \mathrm{AU}$ and 1.43 AU, respectively (Table 4).

Rainfall is a major factor that affecting the growth of the plant. The low and spread of intensity of rainfall can bring a difficulties for farmers to get the forage for cattle, particularly during the dry season. In addition, topography also influences the availability of forage. The land slope is relating to land management and erosion. The land elevation is relating to temperature and solar radiation.

\section{CONCLUSION}

The availability of leucaena as a fodder for Bali cattle in two villages did not meet the cattle need as seen from the dry matter intake and low carrying capacity. Nevertheless the use of leucaena as Bali cattle feed was able to meet the nutrient requirement of crude protein, thereby increasing daily body weight gain of Bali cattle.

\section{REFERENCES}

Abdulrazak, S. A., R. K. Kahindi, \& R. W. Muinga. 2006. Effects of Madras thorn, Leucaena and Gliricidia supplementation on feed intake, digestibility and growth of goats fed Panicum hay. Livest Res Rural Dev. 18 (9).

AOAC. 2005. Official Methods of Analysis. Assoc. Off. Ana. Chem, Washington DC (US).

Aregheore, E. M. \& D. Parera. 2004. Effects of Erythrina variegata, Gliricidia sepium and Leucana leucocephala on dry matter intake and nutrient digestibility of maize stover, before and after spraying with molasses. Anim. Feed Sci. Technol. 111: 191-201. http://dx.doi.org/10.1016/j.anifeedsci.2003.06.001

BPS. 2013. Kupang dalam Angka. Badan Pusat Statistik Kabupaten Kupang.

Dahlanuddin, O. Yanuarianto, D. P. Poppi, S. R. McLennan, \& S. P. Quigley. 2013. Liveweight gain and feed intake of weaned Bali cattle fed grass and tree legumes in West Nusa Tenggara, Indonesia. Anim. Prod. Sci. 54: 915-921.

Fasae, O. A., A. L. Adesope, \& V. O. A. Ojo. 2011. The effect of leucaena leaf supplementation to maize residues on village goat performance. J. Anim. Plant Sci. 10: 1276-1282.

Halls, L. K., R. H. Hughes, R. L. Rummel, \& B. L. Southwel. 1964. Forage and Cattle Management in Longleaf-slaash 
Pine Forest. Farmer's Bulletin Vol. 2119. US Department of Agriculture, Washington.

Haque, N., T. Saroj, M. L. Saraswat, \& M. Y. Khan. 2008. Effect of feeding Leucaena leucocephala leaves and twigs on energy utilization by goats. Anim. Feed Sci. Technol. 142: 330-338. http://dx.doi.org/10.1016/j.anifeedsci.2007.09.027

Hartadi, H., S. Reksohadiprojo, S. Lebdosukojo, A. D. Tillman, L. C. Kearl, \& L. E. Harris. 1980. Tabel-tabel dari Komposisi Bahan Makanan Ternak untuk Indonesia. Published by the International Feedstuffs Institute. Utah Agricultural Experiment Station, Utah State University Logan, Utah.

Herawaty, R., N. Jamarun, M. Zain, Arnim \& R. W. S. Ningrat. 2013. Effect of supplementation Sacharomyces cerevisiae and Leucaena leucocephala on low quality roughage feed in beef cattle diet. Pakistan J. Nutr. 12: 182-184. http://dx.doi. org/10.3923/pjn.2013.182.184

Kanani, J., S. D. Lukefahr, \& R. L. Stanko. 2005. Evaluation of tropical forage legumes (Medicago sative, Dolichos lablab, Leucaena leucocephala and Desmanthus bicornutus) for growing goats. Small Rum. Res. 65: 1-7. http://dx.doi. org/10.1016/j.smallrumres.2005.04.028

Kang, S., M. Wanapat, P. Pakdee, \& A. Cherdthong. 2012. Effects of energy level and Leucaena leucocephala leaf meal as a protein source on rumen fermentation efficiency and digestibility in swamp buffalo. Anim. Feed Sci. Technol. 174: 131-139. http://dx.doi.org/10.1016/j.anifeedsci.2012.03.007

Kearl, L. C. 1982. Nutrient requirements of ruminants in developing countries. International Feedstuffs Institute. Utah Agricultural Experiment Station. Utah State University, Logan Utah.

Lopez, F., M. M. Garcia, R. Yanez, R. Tapiaz, M. Fernandez, \& M. J. Diaz. 2008. Leucaena species valoration for biomass and paper production in 1 and 2 year harvest. Bioeresource. Technol. 99: 4846-4853. http://dx.doi.org/10.1016/ j.biortech.2007.09.048

Metzner, J. K. 1981. Old in the New: Authochonous Approach toward stabilizing an agroecosystem: The case from Amarasi (Timor). App. Geogr. Dev. 17: 1-17.

Nehdy, I. A., S. Hassen, Chin Ping Tan, \& S. I. Al-Resayes. 2014. Leucaena leucocpehala (Lam.) de wit seed oil: Characterization and uses. Ind. Crops. Prod. 52: 582-587. http:// dx.doi.org/10.1016/j.indcrop.2013.11.021
Nulik, J., Dahlanuddin, D. Kana Hau, C. Pakereng, R. G. Edison, D. Liubana, S. P. Ara, \& H. E. Giles. 2013. Esthablisment of Leucaena leucocephala cv. Tarramba in Eastern Indonesia. Trop. Grasslands - Forajes Tropicales. 1: 111-113.

Prasad, J. V. N. S., G. R. Korwar, K. V. Rao, U. K. Mandal, G. R. Rao, I. Srinivas, B. Venkateswarlu, S. N. Rao, \& H. D. Kulkarni. 2011. Optimum stand density of Leucaena leucocephala for wood production in Andhra Pradesh, Southern India. Biomass Bioenergy. 35: 227-235. http://dx.doi. org/10.1016/j.biombioe.2010.08.012

Salem, A. Z. M., M. Olivares, S. Lopez, M. Gonzalez-Ronquillo, R. Rojo, L. M. Camacho, S. M. A. Cerrillo, \& H. P. Meija. 2011. Effect of natural extracts of Salix babylonia and Leucaena leucocephala on nutrient digestibility and growth performance of lambs. Anim. Feed Sci. Technol. 170: 27-34. http://dx.doi.org/10.1016/j.anifeedsci.2011.08.002

Salem, A. Z. M., A. E. Kholif, M. M. Y. Elghandour, G. Buendia, M. D. Mariezcurrena, S. R. Hernandez, \& L. M. Camacho. 2014. Influence of oral administartion of Salix babylonia and Leucaena leococpehala extract on milk production and compositionin dairy cows. Ital. J. Anim. Sci. 13:10-14. http://dx.doi.org/10.4081/ijas.2014.2978

Sharma, A. R. \& U. K. Bahera. 2010. Green leaf manuring with prunings of Leucaena leucocephala for nitrogen economy and improved productivity of maize (Zea mays)-wheat (Triticum aestivum) cropping system. Nutr. Cycl. Agroecosyst. 86:39-52. http://dx.doi.org/10.1007/s10705-009-9272-9

Som, K. R. 1996. Practical Sampling Techniques. 2th ed. Revised and Expanded. Marcel Dekker, Inc. New York.

Tillman, A. D., H. Hartadi, S. Reksohadiprodjo, S. Prawirokusomo, \& S. Lebdosoekojo. 1983. Ilmu Makanan Ternak Dasar. Gadjah Mada University, Yogyakarta.

Yousuf, M. B., M. A. Belewu, J. O. Daramola, \& N. I. Ogundun. 2007. Protein supplementary values of cassava-, leucaenaand gliricidia-leaf meals in goats fed low quality Panicum maximum hay. Livest. Res. Rural Dev. 19(2).

Zurahmah, N. 2011. Pendugaan bobot badan calon pejantan sapi bali menggunakan dimensi ukuran tubuh. Bul Petern. 35: $160-164$. 